УДК 159.9.07

DOI https://doi.org/10.26661/2310-4368/2020-2-15

\title{
ОСОБЛИВОСТІ УЯВЛЕНЬ МОЛОДІ ТА ДОРОСЛИХ ПРО ФАХОВУ ПСИХОЛОГІЧНУ ДОПОМОГУ
}

\author{
Сазонова О. В. \\ кандидат психологічних наук, доцент, \\ доиент кафедри психології \\ Львівський національний університеті імені Івана Франка \\ вул. Університетська, 1, Львів, Україна \\ orcid.org/0000-0001-5884-0633 \\ elenasazonova111@gmail.com
}

\author{
Ключові слова: фахова \\ психологічна допомога, \\ психолог, психологічна \\ служба, психологічна \\ консультаиія, стереотипи \\ щуодо професії психолога, \\ тривожність, толерантність \\ до невизначеності, локус \\ контролю.
}

Стаття присвячена аналізу уявлень про фахову психологічну допомогу та стереотипів щодо професії психолога, яка існує в сучасному світі серед молоді і дорослих людей. Останнім часом тема забезпечення фаховою психологічною допомогою набула неабиякої актуальності. Кількість осіб, що отримують психологічну освіту, зростає. Водночас збільшується і кількість звернень від населення до психологічних центрів за консультацією психолога.

Створені психологічні служби - це структуровані заклади, установи і підрозділи, основу яких складають фахівці в галузі практичної психології (консультанти, аналітики, психологи, соціальні працівники), що виконують специфічні завдання 3 підвищення ефективності життєдіяльності споживачів послуг (клієнтів) засобами прикладної психології i, одночасно, забезпечують захист їхнього психічного здоров'я і соціального благополуччя.

Психологічні служби працюють в декількох напрямках. Один із них освіта, де відбуваються інтенсивні процеси становлення нової педагогіки, яка неможлива без грунтовного психологічного забезпечення навчальновиховного процесу. Інший напрям - система соціальних служб для молоді, де виникає необхідність в організації спеціальної роботи з молодими людьми, що мають життєві проблеми.

Емпіричне дослідження відбувалось письмово, у вигляді тестування в період з 20.02.2020 по 20.03.2020. У дослідженні взяли участь 52 особи: 26 осіб складала молодь та 26 осіб віком старше 40 років. Головним критерієм відбору був вік досліджуваних. Даний віковий склад досліджуваних пов'язаний із різними процесами соціалізації особистостей: особи віком старше 40 зростали в умовах СРСР, де відповідно формувався їх світогляд та певні стереотипи. Методики, використані в дослідженні: авторська анкета, спрямована на виявлення особливостей особистісного ставлення індивідів до фахової психологічної допомоги, методика визначення толерантності до невизначення С. Баднера, методика локусу контролю Д. Роттера, шкала тривожності Тейлора, 16-факторний опитувальник Р.Б. Кеттелла.

Результати математично-статистичного аналізу емпіричних даних дозволяють зробити висновок, що, незалежно від досвіду отримання психологічної допомоги, майже $85 \%$ респондентів вважають іiі ефективною, що свідчить про позитивне ставлення до психологічної служби. Також варто зазначити, що 65\% опитаних виявляють бажання звернутись за психологічною допомогою в майбутньому, що свідчить про зростання потреби у психологічних службах, а також у позитивному ставленні до неї. 
За результатами порівняльного аналізу можна зробити висновок, що серед осіб, які виявляли бажання звернутись за психологічною допомогою в минулому та виявляють бажання звернутись в майбутньому, більшу кількість респондентів складає молодь, що свідчить про менш упереджене ставлення молоді до психологічних служб.

\title{
FEATURES OF PERCEPTION AMONG YOUNG PEOPLE AND ADULTS ABOUT PROFESSIONAL PSYCHOLOGICAL ASSISTANCE
}

\author{
Sazonova O. V. \\ Candidate of Psychological Sciences, Associate Professor, \\ Associate Professor at the Department of Psychology \\ Ivan Franko National University of Lviv \\ Universytetska str., 1, Lviv, Ukraine \\ orcid.org/0000-0001-5884-0633 \\ elenasazonova111@gmail.com
}

Key words: professional
psychological assistance,
psychologist, psychological
service, psychological
consultation, stereotypes
regarding the profession of a
psychologist, anxiety, tolerance to
uncertainty, locus control.
The article is devoted to the analysis of ideas about professional psychological assistance and stereotypes regarding the profession of a psychologist, which exists in the modern world among young people and adults. Recently, the topic of professional psychological assistance has acquired particular relevance. The number of people receiving psychological education is growing. At the same time, the number of appeals from the population to psychological centers for the consultation of a psychologist is also increasing.

The created psychological services are structured institutions, institutions and divisions, which are based on specialists in the field of practical psychology (consultants, analysts, psychologists, social workers), who perform specific tasks to improve the efficiency of the life of service consumers (clients) by means of applied psychology and, at the same time provide protection for their mental health and social well-being.

Psychological services work in several directions. One of them is education, where intensive processes of the formation of a new pedagogy take place, which is impossible without a thorough psychological ensuring of the educational process. Another area is the system of social services for young people, where it becomes necessary to organize special work with young people who have life problems. The empirical study took place in writing, in the form of testing in the period from $20 / 02 / 2020$ to $20 / 03 / 2020$. The study involved 52 people: 26 young people and 26 people - qover the age of 40 . The main selection criterion was the age of the subjects. This age structure is associated with various processes of personality socialization: persons over the age of 40 grew up in the USSR, in accordance with their worldview and certain stereotypes were formed. The methods used in the study: the author's questionnaire aimed at identifying the characteristics of the personal attitude of individuals to professional psychological assistance, the method for determining tolerance to uncertainty by S. Badner, D. Rotter's locus of control method, Taylor's anxiety scale, 16 factor questionnaire by R.B. Cattell.

The results of mathematical and statistical analysis of empirical data allow us to conclude that, regardless of the experience of receiving psychological help, almost $85 \%$ of respondents consider it effective, which indicates a positive attitude towards psychological service. Also, it is worth noting that $65 \%$ of respondents express a desire to seek psychological help in the future, which indicates an increase in the need for psychological services, as well as a positive attitude towards it. 
Based on the results of a comparative analysis, it can be concluded that among those who have expressed a desire to seek psychological help in the past and express a desire to apply in the future, more respondents are young people, which indicates a less biased attitude of young people towards psychological services.

Постановка проблеми. У сучасному світі професія психолога $є$ затребуваною та актуальною. Протягом останніх років неабиякої актуальності набула тема про психологічне забезпечення в Україні. Це свідчить про попит даної професії, а отже, і про збільшення кількості осіб, що звертаються за психологічною допомогою.

Проте вітчизняний менталітет все ще скептично ставиться до професії психолога та не завжди керується довірою до даної професії [9; $10 ; 11 ; 12]$. Тому важливим є дослідити особливості уявлень про фахову психологічну допомогу 3 тим, аби розробити практичні рекомендації щодо розширення спектру уявлень про дану професію в Україні.

Аналіз останніх досліджень і публікацій. Психологічна служба - це цілісна структурована сукупність закладів, установ, підрозділів і посад, що входять до єдиної субординаційної системи, основу якої складають фахівці в галузі прикладної (практичної) психології і яка має специфічні завдання і методи роботи та єдині мету. Зазвичай психологічна служба являє собою сукупність методичних і практичних центрів, спеціалізованих консультативних кабінетів, спеціальних закладів соціальнопсихологічної реабілітації, включає посади консультантів, радників, аналітиків, психологів, соціальних працівників. Основною метою діяльності психологічної служби $€$ підвищення ефективності діяльності персоналу та (або) споживачів послуг (клієнтів) засобами прикладної психології і, одночасно, захист їхнього психічного здоров'я і соціального благополуччя. [8, с. 14].

Психологічні служби працюють в декількох напрямках. Першою галуззю, де сформувався суспільний запит на практичне застосування психологічних знань, $\epsilon$ освіта. Тут відбуваються інтенсивні процеси становлення нової педагогіки, яка неможлива без грунтовного знання про індивідуальність вихованця, учня, студента та особливості міжособистісної взаємодії в навчально-виховному процесі. Необхідність гуманізації та індивідуалізації навчання, втілення в практику ідей дитиноцентризму (В.Г. Кремень) а, значить, застосування новітніх методів навчання, виховання, стимулювання саморозвитку учнів вимагає психологічного забезпечення навчально-виховного процесу [7].

Потреба у кваліфікованій психологічній допомозі відчувається і в такій сфер суспільного життя, як система соиіальних служб для молоді. Іноді виникає необхідність в організації груп психотерапії або психокорекції та проведенні спеціальної роботи з молодими людьми, що мають життєві проблеми. Тож психологи, які працюють у цій службі, іноді практикують як консультанти або керівники тренінгових груп [8].

Проте існує упереджене ставлення до психологів в Україні, на яке впливає чимало факторів, серед них низька обізнаність у даній галузі, особистісні якості, як, наприклад, відсутність довіри, підвищена тривожність, рівень толерантності до невизначеності тощо, а також стереотипи щодо професії психолога.

Мета дослідження полягає в емпіричному дослідженні особливостей уявлень людей про фахову психологічну допомогу в осіб різного віку. Методи дослідження: емпіричні (письмове опитування: тестування, анкетування), математико-статистичні (порівняльний, кореляційний аналізи).

Методика та організація дослідження. Дослідження відбувалось письмово, у вигляді тестування. Тестування відбувалось 3 20.02.2020 по 20.03.2020. Досліджувані проінформовані про конфіденційність та час, виділений на заповнення методик.

У дослідженні взяли участь 52 особи: 26 осіб складала молодь та 26 осіб віком старше 40 років. Головним критерієм відбору був вік досліджуваних. Даний віковий склад досліджуваних пов'язаний із різними процесами соціалізації особистостей: особи віком старше 40 зростали в умовах СРСР, де, відповідно, формувався їхній світогляд та певні стереотипи. Середній вік респондентів складав 35 років.

Серед досліджуваних 39 осіб - жіночої статі (75\%), 13 осіб - чоловічої статі (25\%).

Методики використані в дослідженні: авторська анкета Карковської P.I., методика визначення толерантності до невизначення С. Баднера, методика локусу контролю Д. Роттера, шкала тривожності Тейлора, 16-факторний опитувальник Р.Б. Кеттелла.

Анкета, розроблена Р.І. Карковською, була спрямована на виявлення особливостей особистісного ставлення індивідів до фахової психологічної допомоги. Анкета складалась із 10 питань. Питання були спрямовані на виявлення досвіду отримання фахової психологічної допомоги, оцінку індивідами ефективності фахової психо- 
логічної допомоги, виявлення рівня обізнаності у сфері організацій та фахівців, освітнього рівня батьків тощо. [6]

Виклад основного матеріалу дослідження. Аналіз та опрацювання результатів відбувався у 4 етапи.

Перший eman становив опрацювання результатів анкети. Досвід отримання фахової психологічної допомоги виявлено у 8 осіб $(15,4 \%)$, серед них молодь складає 4 особи $(15,4 \%)$ та дорослих 4 особи $(15,4 \%)$.

Щодо виду отриманої психологічної допомоги: психологічним консультуванням скористались 7 осіб (87,5\%) та 1 особа (12,5\%) - психологічним тренінгом, серед молоді консультування отримали 3 особи (75\%), тренінг - 1 особа (25\%); серед дорослих консультацію отримали 4 особи (100\%).

44 респондента $(84,6 \%)$ не мали досвіду отримання фахової психологічної допомоги, 3 яких молодь складає 22 особи $(84,6 \%)$ та 22 особи дорослих опитуваних. Звернутись за фаховою психологічною допомогою вирішили самостійно 6 досліджуваних (75\%) серед них молодь складає 3 особи (75\%), дорослих - 3 особи $(75 \%)$, скористались порадою друзів 1 особа $(12,5 \%)$ серед дорослих , змусили батьки - 1 особа $(12,5 \%)$ серед молоді.

Серед досліджуваних, що звертались за допомогою, задоволені отриманою психологічною допомогою - 5 осіб $(62,5 \%)$, $з$ яких молодь складає 3 особи (75\%) та дорослі - 2 особи (50\%), дуже задоволені - 2 особи (25\%), що складають дорослі та незадоволені - 1 особа (12,5\%), що складає молодь.

Серед досліджуваних, що не отримували досвід у фаховій психологічній допомозі, виявляли бажання звернутись за нею 21 особа $(47,7 \%)$, серед яких 8 осіб $(36,4 \%)$ складає доросла група та 13 осіб (59\%) серед молоді. Ніколи не виявляли бажання звертатись за психологічною допомогою 23 особи (52,3\%), серед них молодь - 9 опитуваних $(41 \%)$ та 14 осіб $(63,6 \%)$ серед дорослих.

Щодо обізнаності в галузі психологічної допомоги, то 22 особи (42,3\%) зазначили, що їм відомі організації чи спеціалісти, які надають фахову психологічну допомогу, серед них 11 осіб $(42,3 \%)$ складають респонденти дорослої групи та 11 досліджуваних (42,3\%) із групи молоді. 30 осіб $(57,6 \%)$ не обізнані у даній сфері, 3 яких 15 осіб $(57,6 \%)$ складає молодь та 15 осіб $(57,6 \%)$ - респонденти із групи дорослих.

Серед джерел отримання інформації про фахову психологічну допомогу було виявлено такі показники. Щодо групи молоді: інтернет як джерело отримання інформації про психологічну допомогу вказали 3 особи $(21,5 \%)$, знайомих/ родичів - 10 осіб $(71,4 \%)$, та довідник вказала
1 особа (7,1\%). Щодо групи дорослих: знайомих/ родичів як джерело отримання інформації про психологічну допомогу вказали 13 респондентів $(92,8 \%)$ та засоби масової інформації як джерело 1 особа $(7,2 \%)$.

Незалежно від досвіду отримання фахової психологічної допомоги 44 особи $(84,6 \%)$ вважають ii ефективною, серед яких 23 опитуваних із групи молоді $(88,5 \%)$ та 21 особа $(80,8 \%)$ із групи дорослих; 8 осіб $(15,3 \%)$ зазначають, що ії ефективність важко визначити, серед них 5 осіб (19,2\%) складає група дорослих та 3 особи $(11,5 \%)$ - група молоді.

Розглядають можливість звернення за фаховою психологічною допомогою 34 особи $(65,4 \%)$, серед яких 3 групи молоді 20 осіб $(76,9 \%)$ та 14 осіб $(53,8 \%)$ з групи дорослих. Хотіли б отримати психологічну консультацію 16 осіб (47\%), з яких 7 осіб $(50 \%)$ - респонденти з групи дорослих та 9 осіб (45\%) з групи молоді. 15 осіб $(44,2 \%)$ зацікавлені у психотерапії, 3 них 8 (40\%) осіб - група молоді та 7 (50\%) осіб група дорослих. Також 3 особи (15\%) цікавляться психологічним тренінгом та складають групу молоді. 18 опитуваних $(34,6 \%)$ не бажають звертатись за фаховою психологічною допомогою, де 12 осіб (46,2\%) складають респонденти із групи дорослих та 6 осіб $(23,1 \%)$ iз групи молоді.

Щодо зазначеної причини відмови звернення за психологічною допомогою, то 6 осіб $(33,3 \%)$ зазначають, що не люблять ділитись своїми думками та переживаннями 3 іншими, серед яких 2 особи $(33,3 \%)$ - молодь та 4 особи $(33,3 \%)$ - доросла група. 3 особи $(16,7 \%)$ відповіли, що ніколи не відчували потреби щось в собі змінювати чи розвивати, серед них 1 особа $(16,7 \%)$ склала молодь та 2 особи (16,7\%) - дорослі. 9 осіб (50\%) стверджують, що здатні самі вирішити свої проблеми чи розв'язати життєві задачі, 3 яких 3 особи (50\%) - респонденти із групи молоді та 6 осіб (50\%) - із групи дорослих.

Другий eman складає опрацювання та аналіз результатів методик. Проаналізувавши методику толерантності до невизначеності С. Баднера, можна зробити такі висновки: у 23 осіб (44,2\%) виявлено середній рівень толерантності до невизначеності, серед них 16 осіб (61,5\%) склали респонденти групи дорослих та 7 осіб $(29,6 \%)$ iз групи молоді. У 16 осіб $(30,8 \%)$ - низький рівень толерантності, з яких 13 осіб (50\%) складає вибірка молоді та 3 особи $(11,6 \%)$ - вибірка дорослих. 13 осіб (25\%) складають досліджувані 3 високим рівнем, що свідчить про високу інтолерантність до невизначеності, серед них 6 осіб $(23,1 \%)$ склала молодь та 7 осіб $(29,6 \%)$ - група дорослих (рис. 1). 


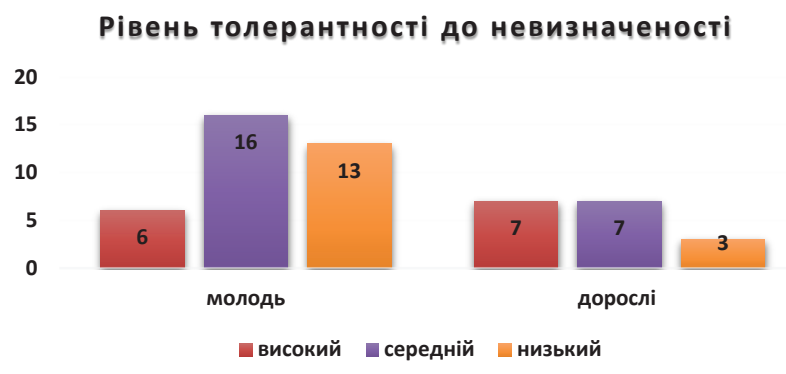

Рис. 1. Діаграма зображує різницю у рівні толерантності до невизначеності респондентів двох груп

Щодо опрацювання результатів методики Дж. Роттера, то з метою діагностики локусу контролю досліджуваних виявлено такі дані: 31 особу $(59,6 \%)$ складають інтернали, серед них 17 опитаних $(63,4 \%)$ складають групу дорослих та 14 осіб $(53,8 \%)$ складають групу молоді. У 21 особи $(40,4 \%)$ виявлено екстернальний тип поведінки, з яких 12 осіб $(46,2 \%)-$ респонденти із групи молоді та 9 осіб $(34,6 \%)$ опитані із групи дорослих. (рис. 2).

\section{Локус контролю}

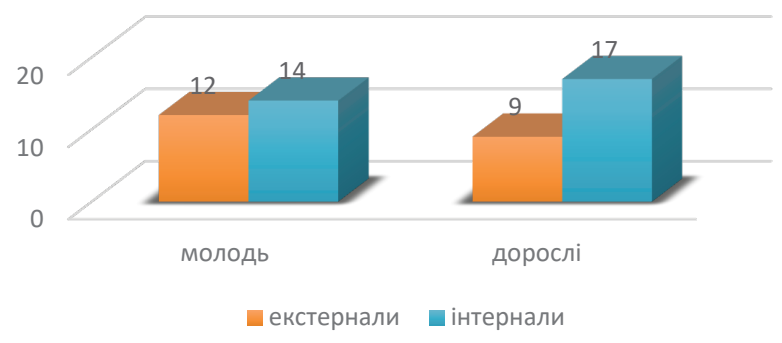

Рис. 2. Діаграма зображує поділ респондентів за локусом контролю за групами

Опрацювавши результати шкали тривожності Тейлора (в адаптації М.М. Пейсахова), можна зазначити такі дані: низький рівень тривожності виявлено у 29 осіб $(55,8 \%)$, серед них 17 осіб (63,4\%) - досліджувані із групи дорослих та 12 осіб $(46,1 \%)$ - із групи молоді. Середній рівень спостерігається у 9 осіб $(17,3 \%), 3$ них 1 особа $(3,8 \%)$ складає вибірку дорослих та 8 осіб (30,7\%) - вибірку молоді. Високий рівень зазначено у 14 осіб (26,9\%), з яких 6 досліджуваних $(23,2 \%)$ складають групу молоді та 8 осіб (30,8\%) - групу дорослих (рис. 3).

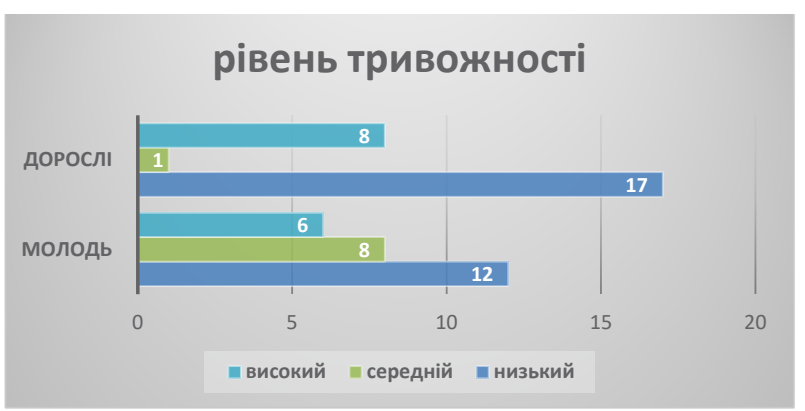

Рис. 3. Діаграми зображус рівень тривожності респондентів

Tpemiŭ eman. Для того аби виявити відмінності між особистісними характеристиками досліджуваних у групі молоді та групі дорослих, був проведений порівняльний аналіз учасників дослідження із застосуванням t-критерію Ст'юдента та $\chi 2$ - Пірсона. Проаналізувавши результати дескриптивного аналізу та статистичного аналізу нормального розподілу даних, можна зазначити такі результати.

У групі дорослих: між підгрупами, що отримали психологічну допомогу та не отримали, виявлено відмінності за шкалами підпорядкованість/домінантність; боязкість/сміливість; та жорсткість/чутливість. У групі молоді виявлено певні відмінності за шкалами інтелекту та емоційної стабільності, проте вони не є статистично значущими.

Групи дорослих та молоді, що не отримали психологічну допомогу, згідно 3 порівняльним аналізом відрізняються за такими показниками: інтелект, емоційна стабільність/емоційна нестабільність. У дорослих більш високий інтелект, а в молоді вищі показники емоційної стабільності (рис. 4). Отже, можна зробити висновок, що молодь більше керується емоційною сферою, а дорослі - когнітивною. Можна припустити, що молодь відмовляється від психологічної допомоги через відчуття «не хочу», а дорослі - через думку «мені це не потрібно».

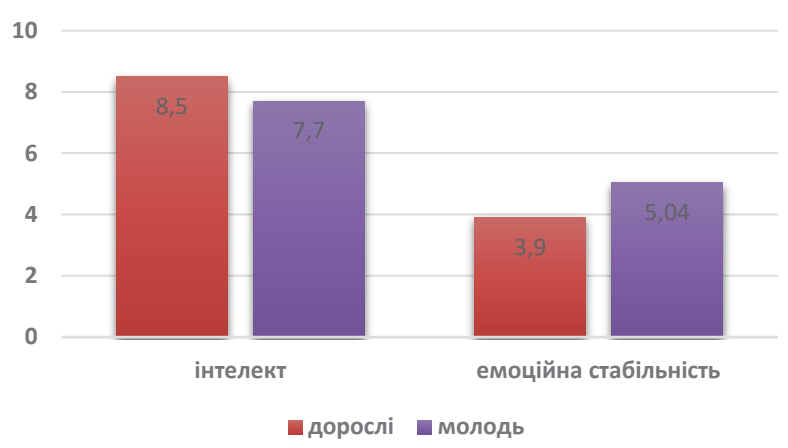

Рис. 4. Відмінності середніх значень осіб, що не отримали психологічну допомогу 
Групи дорослих та молоді, що отримали психологічну допомогу, відрізняються за шкалами підпорядкованість/домінантність, боязкість/ сміливість, жорсткість/чутливість, довірливість/підозрілість. У дорослих більш виражені домінантність, сміливість, чутливість та підозрілість, ніж у молоді (рис. 5). Тобто дорослі, що звертаються за психологічною допомогою, більш незалежні та обережні у своєму виборі та частіше готові до співпраці з незнайомими людьми, ніж молодь.

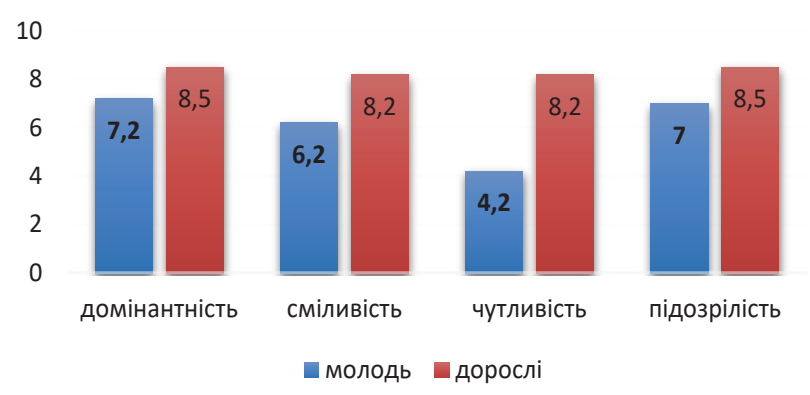

Рис. 5. Відмінності середніх значень осіб, що отримали психологічну допомогу

У групі дорослих, що виявляли бажання звернутись за психологічною допомогою в минулому та не виявляли, спостерігаються відмінності за шкалою підпорядкованість/домінантність. У групі молоді виявлено відмінності за шкалою жорсткість/чутливість.

Серед груп молоді та дорослих, що виявляли бажання отримати допомогу, спостерігаються відмінності за шкалами замкнутість/товариськість, інтелекту (рис. 6). Тобто дорослі, які ніколи не отримували психологічну допомогу, проте розглядали можливість звернення, також більше керуються когнітивною сферою та думкою про те, що «це потрібно».

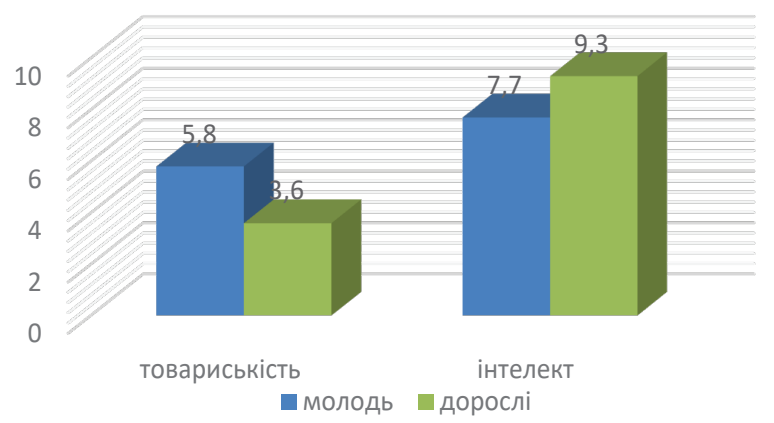

Рис. 6. Відмінності середніх значень осіб, що виявляли бажання звернутись за психологічною допомогою у минулому
Серед груп молоді та дорослих, що не виявляли бажання отримати психологічну допомогу, виявлено відмінності за шкалами тривожності, в молоді виявлено вищий рівень (рис. 7). Тобто можна припустити, що молодь, яка не виявляла бажання звернутись за допомогою, не зробила цього саме через підвищену тривожність.

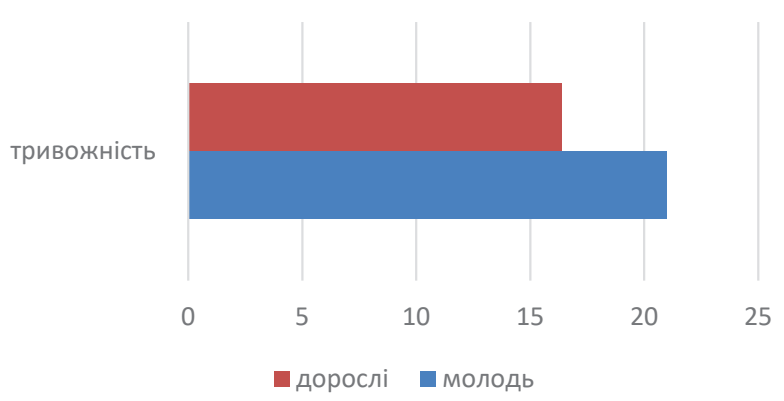

Рис. 7. Відмінності середніх значень осіб, що не виявляли бажання звернутись за психологічною допомогою у минулому

Щодо осіб, які отримали психологічну консультацію та психологічний тренінг, виявлено такі відмінності. У групі молоді спостерігаються відмінності за шкалою розслабленості/напруженості. Також можна виділити відмінності за рівнем толерантності до невизначеності, за шкалою консерватизму/радикалізму, емоційної стабільності, конформізму, проте дані відмінності є статистично не значущими. У групі дорослих респондентів, що звертались за тренінгом, не виявлено.

Серед молоді та дорослих, що отримали консультацію, спостерігаються відмінності за шкалами боязкість/сміливість, жорсткість/чутливість та конформності (рис. 8). Отже, в дорослих виявлено вищий рівень сміливості, чутливості, а в молоді - конформності. Можна зробити висновок, що дорослі, які отримали консультацію, були також незалежними у своєму виборі та не керувались думкою інших в порівнянні з молоддю.

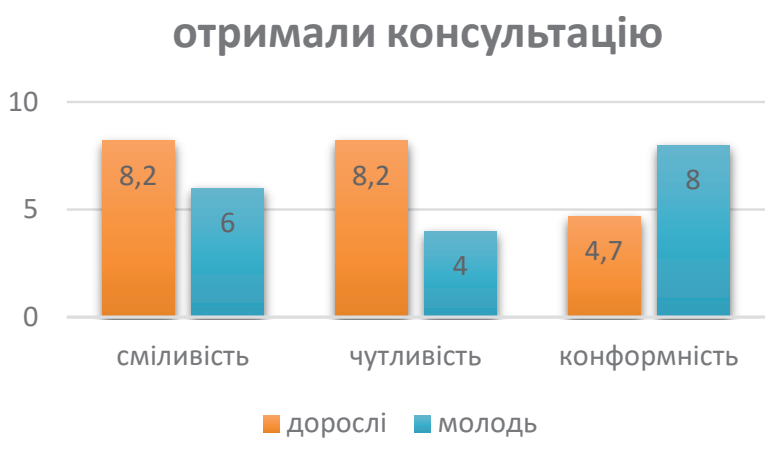

Рис. 8. Відмінності середніх значень осіб, що отримали психологічну консультацію 
Серед оцінки респондентами отриманої психологічної допомоги у групі дорослих можна зазначити 2 критерії: задоволені та дуже задоволені. Значущі відмінності спостерігаються за шкалою сміливості, що свідчить про значно вищий рівень сміливості в осіб, що дуже задоволені отриманою допомогою. У групі молоді також можна виокремити 2 критерії: не задоволені та задоволені. Значні відмінності виявлено за шкалою самоконтролю. Тобто в осіб, що не задоволені отриманими психологічними послугами, значно вищий рівень самоконтролю.

Серед молоді та дорослих, що задоволені отриманою допомогою, спостерігаються відмінності за шкалами тривожності та довірливості/підозрілості, що свідчить про вищий рівень тривожності та підозрілості в дорослих (рис. 9). Тож можна припустити, що в наданні оцінки отриманій допомозі дорослі є більш автономними у своєму виборі, ніж молодь, та не керуються соціально прийнятними нормами.

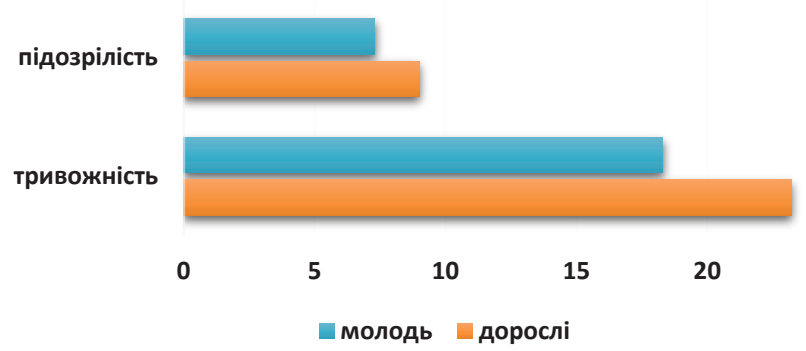

Рис. 9. Відмінності середніх значень осіб, що задоволені отриманою психологічною допомогою

Щодо обізнаності у сфері психологічних організацій та спеціалістів, то у групі дорослих виявлено відмінності за шкалами довірливість/підозрілість та самоконтроль. У групі молоді відмінності спостерігаються за шкалою супер-его.

Серед груп молоді та дорослих, що обізнані в організаціях, виявлено відмінності за шкалою довірливості/підозрілості (рис. 10). Тобто у групі дорослих вищий рівень підозрілості. Можна припустити, що дорослі, що обізнані у сфері організацій, $є$ більш обережними та настороженими у відношенні до невизначеності, отже, надають перевагу бути обізнаними у сфері того питання, що їх цікавить, ніж молодь. Серед молоді та дорослих, що не обізнані в організаціях, значних відмінностей не виявлено.

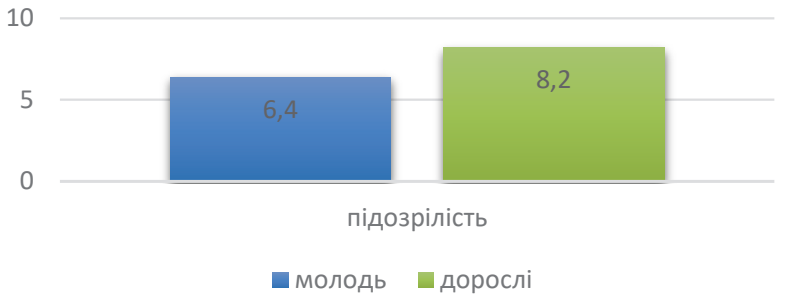

Рис. 10. Відмінності середніх значень осіб, що обізнані у сфері психологічних організацій

У групі дорослих щодо оцінки ефективності психологічної допомоги незалежно від досвіду отримання виявлено значущі відмінності за шкалами підпорядкованість/домінантність, боязкість/сміливість, жорсткість/чутливість. У групі молоді виявлено відмінності за шкалами емоційної стабільності, підпорядкованості/ домінантності та розслабленості/напруженості. Тобто дорослі, що оцінюють фахову психологічну допомогу як ефективну, більш сміливі, незалежні та емоційні у своїх твердженнях, ніж дорослі, що надають оцінку як «важко сказати». Молодь, що оцінює психологічну допомогу як ефективну, більш емоційно стабільна та незалежна, ніж молодь, що обрала відповідь «важко сказати», отже, можна припустити, що дана оцінка базувалась на власних переконаннях респондентів.

Серед груп молоді та дорослих, що оцінюють психологічну допомогу як ефективну, значних відмінностей не виявлено. Аналогічно серед молоді та дорослих, що обрали варіант відповіді «важко сказати».

Щодо розгляду звернення за фаховою психологічною допомогою, то у групі дорослих виявлено відмінності за рівнем тривожності. У групі молоді виявлено відмінності за шкалами інтелекту; підпорядкованості/домінантності; жорсткості/чутливості та довірливості/підозрілості. Можна зробити висновок, що в обох групах особи, що зацікавлені у психологічній допомозі в майбутньому, $є$ більш тривожними, проте керуються когнітивною сферою та розуміють, що їм потрібна дана допомога, отже, є незалежні у своєму виборі щодо майбутнього звернення по допомогу.

Серед осіб, що бажають звернутись за психологічною допомогою, в обох групах значних відмінностей не виявлено. Серед досліджуваних, що не бажають отримати психологічну допомогу, виявлено відмінності за шкалою інтелекту. У групі дорослих вищий інтелект, ніж у групі молоді (рис. 11). Тож можна сказати, що дорослі більше керуються когнітивною сферою та розумінням необхідності у психологічній допомозі. 


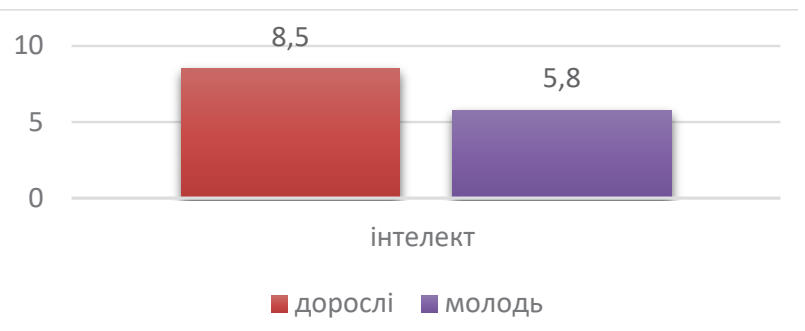

Рис. 11. Відмінності середніх значень осіб, що не бажають отримати психологічну допомогу у майбутньому

Щодо джерел отримання інформації про фахову психологічну допомогу, то можна виділити такі критерії, як: отримали інформацію через родичів/знайомих, ЗМІ, Інтернет, з довідника. У групі молоді виявлено 3 критерії: через родичів/знайомих, інтернет, довідник. Статистично значущі відмінності виявлено за шкалою супер-его, довірливість/підозрілість. В осіб, що отримали інформацію, вищий рівень супер-его, а в осіб, що отримали інформацію з Інтернету, вищий рівень підозрілості. Також відмінності спостерігаються за діагностикою локусу контролю та шкалою інтелекту: в осіб, що отримували інформацію через родичів/знайомих, більше виражена інтернальність та вищий рівень інтелекту. Проте дані відмінності не є статистично значущими.

У групі дорослих виявлено 2 критерії: отримували інформацію через 3МI та через знайомих. Відмінності виявлено за рівнем толерантності до невизначеності та рівнем напруги. У групи, що отримувала інформацію від родичів/знайомих, вищий рівень інтолерантності до невизначеності та напруги. Отже, в дорослих, що отримали інформацію через знайомих, високий рівень інтолерантності до невизначеності та рівень напруги.

Проте суттєвих відмінностей між групою дорослих та молоді за різницею у джерелах отримання інформації про фахову психологічну допомогу не виявлено.

У групі дорослих щодо бажаного виду $\boldsymbol{n c u - ~}$ хологічних послуг виявлено 2 критерії: особи, що цікавляться консультацією, та особи, що цікавляться психотерапією. Спостерігаються відмінності за шкалами інтелекту, підпорядкованості/домінантності та жорсткість/чутливість. Отже, в осіб, що хочуть звернутись за терапією, вищі показники інтелекту, домінантності та чутливості, тому можна зробити висновок, що вибір даної психологічної послуги $\epsilon$ незалежним та обміркованим, оскільки дорослі в даній підгрупі більше керуються когнітивною сферою.
У групі молоді виявлено такі відмінності: за психотерапією здебільшого звернуться інтернали. В осіб, що хочуть звернутись за консультацією, виявлено вищий рівень інтелекту. Проте дані відмінності не є статистично значущими.

Серед груп молоді та дорослих, що хочуть отримати консультацію, значних відмінностей не виявлено. Серед молоді та дорослих, що хочуть отримати психотерапію, також не виявлено суттєвих відмінностей.

Серед осіб, які не бажають отримати психологічну допомогу, в майбутньому виявлено 3 критерії: особи, що ніколи не відчували потреби щось у собі змінювати; особи, що здатні самі вирішити свої проблеми чи розв'язати життєві негаразди; особи, що не люблять ділитись своїми переживаннями з іншими.

У групі дорослих статистично суттєвих відмінностей не виявлено. Аналогічно не виявлено статистично значущих відмінностей у групі молоді.

Серед осіб, що ніколи не відчували потреби у психологічній допомозі, у групі молоді та групі дорослих відмінностей не виявлено. Серед осіб, що здатні самі вирішити свої життєві негаразди, у групі дорослих виявлено вищі показники за шкалами інтелекту, отже, можна сказати, що дорослі керуються когнітивною сферою та під час прийняття рішення $\epsilon$ більш раціональними, ніж молодь (рис. 12).

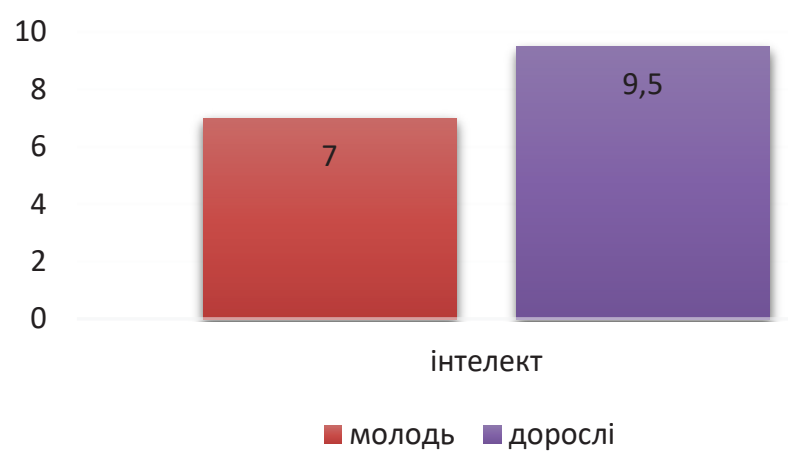

Рис. 12. Відмінності середніх значень осіб, що здатні самі вирішити життєві негаразди

Серед осіб, що не люблять ділитись своїми переживаннями з іншими, у групі дорослих виявлено вищі результати за рівнем інтелекту, ніж у групі молоді. Тож можна сказати, що дорослі в даній підгрупі також керуються когнітивною сферою та $є$ більш раціональні у своєму рішенні чи виборі (рис. 13). 
15

10

5

0

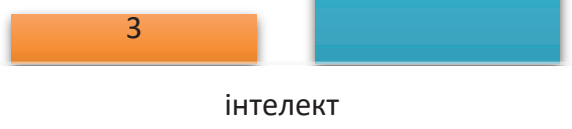

молодь дорослі

Рис. 13. Відмінності середніх значень осіб, що не люблять ділитись своїми переживаннями

Четвертий eman. Для того щоб виявити взаємозв'язки між емпіричними показниками, був застосований кореляційний аналіз. У досліджуваній групі дорослих було проведено два кореляційні аналізи: перший - між особами, що отримали психологічну допомогу, та особами, що не отримували; другий - між особами, що вважають психологічну допомогу ефективною та ставляться до неї нейтрально, незалежно від досвіду iii отримання.

Серед дорослих, що отримали психологічну допомогу, виявлено такі кореляційні зв'язки. Пряму кореляцію не виявлено. Обернену кореляцію виявлено між шкалами «тривожності» та «інтелекту» ( $\mathrm{r}=-0,99 ; \mathrm{p}=<0,5), \quad$ «тривожності» та «підпорядкованості/домінантності» ( $\mathrm{r}=-0,99$; $\mathrm{p}=<0,5)$, методикою «локусу контролю» та субшкалою «новизни» методики толерантності до невизначеності.

Дані результати свідчать про те, що під час зростання рівня тривожності буде зменшуватись рівень домінантності та інтелект, а також, що під час збільшення рівня інтернальності знижується інтолерантість до невизначеності, яка спричинена страхом перед новизною.

Серед дорослих, що не отримали фахову психологічну допомогу, виявлено такі кореляційні зв'язки. Пряма кореляція спостерігається за шкалами «тривожності» та діагностикою «локусу контролю» $(\mathrm{r}=0,42 ; \mathrm{p}=<0,5)$, «тривожності» та «розслабленості/ напруженості» $(\mathrm{r}=0,49 ; \mathrm{p}=<0,5)$, між субшкалою «нерозв'язності» методики «толерантність до невизначеності» та «консерватизмом/ радикалізмом» $(\mathrm{r}=0,54 ; \mathrm{p}=<0,5)$. Обернену кореляцію виявлено між методикою діагностики «локусу контролю» та методикою «толерантності до невизначеності» $(\mathrm{r}=-0,44 \mathrm{p}=<0,5)$, а також шкалою «консерватизму/радикалізму» $(\mathrm{r}=-0,45 \mathrm{p}=<0,5)$, між методикою «толерантності до невизначеності» та шкалою «довірливість/підозрілість» $(\mathrm{r}=-$ $0,47 \mathrm{p}=<0,5)$, також між субшкалою «новизни» методики «толерантність до невизначеності» та «довірливістю/підозрілістю» $(\mathrm{r}=-0,51, \mathrm{p}=<0,5)$.
Дані результати свідчать про те, що в дорослих, які не отримали психологічну консультацію, зі зростанням тривожності зростає рівень напруженості, також тривожність більше виражена в інтерналів, а чим вищий рівень радикалізму, тим вищий страх перед нерозв'язністю. Також можна сказати, що зі збільшенням рівня інтернальності знижується рівень інтолерантності до невизначеності та рівень радикалізму. Також зі збільшенням рівня інтолерантності, що спричинена страхом перед новизною, зменшується рівень підозрілості.

Серед дорослих, що вважають фахову психологічну допомогу ефективною незалежно від досвіду отримання даної, виявлено такі кореляційні зв'язки. Пряма кореляція спостерігається між шкалою «тривожності» та «розслабленість/ напруженість» $(\mathrm{r}=0,47, \mathrm{p}=<0,5)$, між методикою діагностики «локусу контролю» та шкалою «домінантності» $(\mathrm{r}=0,49, \mathrm{p}=<0,5)$. Обернена кореляція спостерігається між шкалою «тривожності» та «емоц. нестабільності/ емоц. стабільності» $(\mathrm{r}=-0,51, \mathrm{p}=<0,5)$. Методика діагностики «локусу контролю» обернено корелює 3 методикою «толерантності до невизначеності» $(\mathrm{r}=-0,59, \mathrm{p}=<0,5)$. Також виявлено обернену кореляцію між субшкалами новизни та «довірливістю/підозрілістю» ( $\mathrm{r}=-$ $0,46, \mathrm{p}=<0,5)$, субшкалою «складності» та «конформності» $(\mathrm{r}=-0,46, \mathrm{p}=<0,5)$.

Дані результати свідчать про те, що в дорослих, які вважають психологічну допомогу ефективною, під час зростанні рівня тривожності зростатиме рівень напруженості та зменшуватиметься рівень емоційної стабільності, в інтерналів більш виражена домінантність та знижений рівень інтолерантності до невизначеності. Також зі зростанням рівня підозрілості зменшуватиметься страх перед новизною, а зі зростанням рівня конформності зменшуватиметься страх перед складністю.

Серед дорослих, що відносяться до психологічної допомоги нейтрально, прямої кореляції не виявлено. Обернені кореляційні зв'язки спостерігаються між шкалою «тривожності» та «самоконтрою» $(\mathrm{r}=-0,90, \mathrm{p}=<0,5)$, методикою діагностики «локусу контролю» та «конформністю» $(\mathrm{r}=-0,96$, $\mathrm{p}=<0,5)$. Дані результати свідчать про те, що в дорослих, що ставляться до психологічної допомоги нейтрально, зі зростанням рівня тривожності зменшуватиметься рівень самоконтролю, а зі зростанням інтернальності знижуватиметься рівень конформності.

У групі молоді також було проведено два аналогічні кореляційні аналізи: перший - між особами, що отримали психологічну допомогу, та особами, що не отримували; другий - між особами, що вважають психологічну допомогу ефективною та ставляться до неї нейтрально незалежно від досвіду її отримання. 
Серед молоді, що отримала психологічну допомогу, виявлено такі кореляційні зв'язки. Пряма кореляція спостерігається між методикою «толерантності до невизначеності» та шкалою «емоц. нестабільності/ емоц. стабільності» ( $\mathrm{r}=0,98$; $\mathrm{p}=<0,5)$, а також між шкалою «боязкість/ сміливість» та субшкалою «новизни» методики «толерантність до невизначеності» $(\mathrm{r}=0,98 ; \mathrm{p}=<0,5)$. Обернену кореляцію виявлено між субшкалою «складності» методики «толерантність до невизначеності» та шкалою «розслабленості/ напруженості» $(\mathrm{r}=-0,98 \mathrm{p}=<0,5)$.

Дані результати свідчать про те, що в молоді, яка отримала психологічну допомогу, зі збільшенням рівня інтолерантності збільшується рівень емоційної стабільності, а також зі збільшенням рівня страху перед новизною збільшується рівень сміливості. Зі зростанням рівня страху перед складністю зменшуватиметься рівень напруженості.

Серед молоді, що не отримала психологічну допомогу, виявлено такі кореляційні зв'язки. Прямі кореляційні зв'язки виявлено між шкалою «тривожності» та «розслабленості/напруженості» $(\mathrm{r}=0,53 ; \mathrm{p}=<0,5)$. Обернено корелює шкала «тривожності» із шкалами «емоц. нестабільності/ емоц. стабільності» $(\mathrm{r}=-0,51 \mathrm{p}=<0,5)$, та «підпорядкованості/ домінантності» $(\mathrm{r}=-0,42 \mathrm{p}=<0,5)$.

Проаналізувавши отримані результати, можна сказати, що в молоді, яка не отримала психологічну допомогу, зі зростанням рівня тривожності збільшуватиметься рівень напруженості та зменшуватиметься рівень емоційної стабільності та домінантності.

Серед молоді, що вважає фахову психологічну допомогу ефективною, виявлено такі кореляційні зв'язки. Пряма кореляція спостерігається між шкалами «тривожності» та «розслабленості/ напруженості» $(\mathrm{r}=0,50 ; \mathrm{p}=<0,5)$. Також пряму кореляцію субшкали «складності» виявлено зі шкалою «жорсткість/чутливість» $(\mathrm{r}=0,46$; $\mathrm{p}=<0,5)$, «боязкість/сміливість» $(\mathrm{r}=0,48 ; \mathrm{p}=<0,5)$, та «замкутість/товариськість» $(\mathrm{r}=0,48 ; \mathrm{p}=<0,5)$, а також між шкалою «нерозв' язності» та «конформності» $(\mathrm{r}=0,42 ; \mathrm{p}=<0,5)$. Обернену кореляцію не виявлено.

Дані результати свідчать про те, що в молоді, яка вважає психологічну допомогу ефективною, зі зростанням рівня тривожності зростатиме рівень напруги, зі зростанням рівня страху перед складністю зростатиме рівень чутливості, сміливості та товариськості, а зі зростанням рівня страху перед нерозв'язністю зростатиме рівень конформності.

Серед молоді, що вважає психологічну допомогу нейтральною, виявлено пряму кореляцію між шкалою «тривожності» та новизни $(\mathrm{r}=0,99$; $\mathrm{p}=<0,5)$, методикою толерантності до невизна- ченості та «самоконтролем» $(\mathrm{r}=1,00 ; \mathrm{p}=<0,5)$, методикою діагностики «локусу контролю» та субшкалою «складності» $(\mathrm{r}=1,00 ; \mathrm{p}=<0,5)$. Обернену кореляцію можна спостерігати між шкалою «замкнутість/товариськість» та шкалами «тривожність» $(\mathrm{r}=-0,99 ; \mathrm{p}=<0,5)$ та «новизна» $(\mathrm{r}=-0,99$; $\mathrm{p}=<0,5)$, методика «толерантності до невизначеності обернено корелює зі шкалою «жорсткість/чутливість» $(\mathrm{r}=-1,00 ; \mathrm{p}=<0,5)$ та «інтелекту» $(\mathrm{r}=-1,00$; $\mathrm{p}=<0,5)$, а шкала «консерватизм/радикалізм» - iз субшкалою «нерозв'язності» $(\mathrm{r}=-0,99 ; \mathrm{p}=<0,5)$.

Дані результати свідчать про те, що в молоді, яка вважає психологічну допомогу нейтральною, зі зростанням рівня тривожності зростатиме страх перед новизною та знижуватиметься рівень товариськості, зі зростанням рівня інтолерантності зростатиме рівень самоконтролю та знижуватиметься рівень чутливості та інтелекту, зі зростанням рівня інтернальності зростатиме рівень страху перед складністю, зі зростанням рівня страху перед новизною знижується рівень товариськості, а зі зростанням рівня радикалізму знижуватиметься страх перед нерозв'язністю.

Висновки та перспективи подальших досліджень. Соціальні уявлення - це складне утворення у стуркутрі свідомості особистості, що базується на пануючих у суспільстві ідеях, цінностях, думках, знаннях та практиках, що формувались та передавались протягом століть.

Соціальні уявлення відіграють важливу роль у процесі становлення та соціалізації особистості. Вони є інструментами пізнання, за допомогою чого здійснюється процес адаптації та опосередкування поведінки особистості. Тобто спочатку новий предмет (об'єкт, явище, ситуація) приваблює увагу індивіда, потім відбувається процес інтерпретації, після чого вибудовується модель поведінки особистості, яка включається в особисту когнітивну структуру відповідно до картини світу $[2 ; 3 ; 5]$.

Процес становлення особистості відбувається шляхом соціалізації, тобто поступового засвоєння нею вимог суспільства, надбання соціально значимих характеристик свідомості і поведінки, які регулюють ï взаємини із суспільством. Процес соціалізації відбувається завдяки комунікаціям особистості у групах, стихійному впливу на індивіда та «свідомому впливу», якому особистість щоденно піддається у соціумі $[1 ; 4]$.

Проінтерпретувавши результати емпіричного дослідження особливостей уявлень людей про фахову психологічну допомогу в осіб різного віку, бачимо, що дорослі та молодь, що отримали фахову психологічну допомогу, задоволені нею, проте серед осіб, що не отримували психологічну допомогу, більша кількість опитаних ніколи не думала звертатись по неї. Крім того, незалежно 
від досвіду отримання психологічної допомоги майже $85 \%$ респондентів вважають іiі ефективною, що свідчить про позитивне ставлення до психологічної служби. Також варто зазначити, що $65 \%$ опитаних виявляють бажання звернутись за психологічною допомогою в майбутньому, що свідчить про зростання потреби у психологічних службах, а також у позитивному ставленні до неї.

За результатами порівняльного аналізу можна зробити висновок, що серед осіб, які виявляли бажання звернутись за психологічною допомогою в минулому та виявляють бажання звернутись у майбутньому, більшу кількість респондентів складає молодь, що свідчить про менш упереджене ставлення молоді до психологічних служб.

Також виявлено, що рівень тривожності, рівень толерантності до невизначеності та локусу контр- олю не впливає на ставлення до фахової психологічної допомоги. Отже, можна зробити висновок, що у ставленні до психологічної допомоги, за даним дослідженням, має значення тільки віковий діапазон.

Отже, для покращення ставлення до особистості психолога та психологічних служб у цілому необхідно перш за все розвіяти міфи та стереотипи, сформовані раніше. Оскільки ми живемо у час розвитку технологій, важливо запроваджувати більше інформації щодо психологічних служб через засоби масової інформації та телекомунікації, для того, аби люди краще розуміли специфіку професії психолога. Проте, звичайно, все залежить від індивідуальних характеристик особистості та іiі бажання розвиватись особистісно та збагачувати знання.

\section{ЛІТЕРАТУРА}

1. Абульханова К.А. Социальное мышление личности. Современная психология: состояние и перспективы исследований. Ч. 3. Сочиальные представления и мышление личности. Москва : Изд-во «Институт психологии РАН», 2002. С. 88-103.

2. Бондаренко Л.О. Феномен соціальних уявлень у сучасній психології. Актуальні проблеми психології: Збірник наукових праџь Інституту психології імені Г.С. Костюка. Психологія навчання. Генетична психологія. Медична психологія. 2013. Том. Х. Вип. 25. С. 55-63.

3. Вербицкий Р.Ю. Социальные представления как предмет социальной психологии. Вестник Универcumema. 2015. № 1. C. 311-314.

4. Галус О.М. Соціалізація особистості: сутність, концептуальні підходи у наукових теоріях, напрямках, школах. Збірник наукових прачь Хмельнищького інституту сочіальних технологій Університету «Україна». 2010. № 2. С. 69-75.

5. Камінська С.В. Теоретичний аналіз наукових підходів до проблеми соціальних уявлень у психологічних дослідженнях. Науковий вісник Херсонського державного університету. Серія: Психологічні науки. 2014. Вип. 2.2. С. 32-36.

6. Карковська Р. Ставлення студентів до фахової психологічної допомоги. Тези звітної наукової конференцї філософського факультету. Випуск 8. Відп. за випуск проф. В. Мельник. Львів : Видавничий центр ЛНУ імені Івана Франка, 2011. С. 183-187.

7. Костюк Г.С. Навчально-виховний процес і психічний розвиток особистості. Київ : Рад. школа, 1989. $608 \mathrm{c}$.

8. Панок В.Г. (наук. ред.), Обухівська А.Г., Острова В.Д. та ін. Психологічна служба : підруч. Київ : Ніка-Центр, 2016. 259 с.

9. Страх з СРСР: чому українці бояться психологів. 24 здоров’я. URL : https://24tv.ua/health/strah_z_ srsr_chomu_ukrayintsiv_boyatsya_psihologiv_n1093722 (дата звернення: 01.03.2020).

10. Страх психологов и психотерапии. URL : https://www.b17.ru/article/73131/ (дата звернення: 20.02.2020).

11. Cossum Gr. Why are some people afraid of psychologists? URL : https://www.quora.com/Why-are-somepeople-afraid-of-psychologists-therapists (дата звернення: 27.03.2020).

12. Hale M. 5 Common Fears That Keep People Out Of Therapy // Mental Health. URL : https://www.mindbodygreen.com/0-13317/5-common-fears-that-keep-people-out-of-therapy.html (дата звернення 15.03.2020).

\section{REFERENCES}

1. Abulkhanova, K.A. (2002) Soczialnoe myshlenie lichnosti [Social thinking of personality]. Sovremennaya psikhologiya: sostoyanie i perspektivy issledovanij. Soczialnye predstavleniya i myshlenie lichnostiModern psychology: state and research prospects. Social representations and thinking of the individua, 3, 88-103 [in Russian]

2. Bondarenko, L. O. (2013) Fenomen sotsialnykh uiavlen u suchasnii psykholohii [The phenomenon of social ideas in modern psychology]. Aktualni problemy psykholohii: Psykholohiia navchannia. Hene- 
tychna psykholohiia. Medychna psykholohiia-Current problems of psychology: Psychology of learning. Genetic psychology. Medical psychology, (Vols. X), 25, 55-63 [in Ukrainian]

3. Verbiczkij, R.Y. (2015) Soczialnye predstavleniya kak predmet soczialnoj psikhologii [Social representations as a subject of social psychology]. Vestnik Universiteta - University Bulletin, 11, 311-314 [in Russian]

4. Halus, O.M. (2010) Sotsializatsiia osobystosti: sutnist, kontseptualni pidkhody u naukovykh teoriiakh, napriamkakh, shkolakh [Socialization of personality: essence, conceptual approaches in scientific theories, directions, schools]. Zbirnyk naukovykh prats Khmelnytskoho instytutu sotsialnykh tekhnolohii Universytetu «Ukraina» - Collection of scientific works of the Khmelnytsky Institute of Social Technologies of the University "Ukraine", 2, 69-75 [in Ukrainian]

5. Kaminska, S.V. (2014) Teoretychnyi analiz naukovykh pidkhodiv do problemy sotsialnykh uiavlen u psykholohichnykh doslidzhenniakh [Theoretical analysis of scientific approaches to the problem of social ideas in psychological research]. Naukovyi visnyk Khersonskoho derzhavnoho universytetu. Seriia: Psykholohichni nauky - Scientific Bulletin of Kherson State University. Psychological sciences, 2.2, 32-36 [in Ukrainian]

6. Karkovska, R. (2011) Stavlennia studentiv do fakhovoi psykholohichnoi dopomohy [Attitudes of students to professional psychological care]. Proceedings from MIIM '11: Zvitna naukova konferentsiia filosofskoho fakultetu - Reporting scientific-practical conference of the Faculty of Philosophy. (8, pp.183 - 187) Lviv: Vydavnychyi tsentr LNU imeni Ivana Franka [in Ukrainian]

7. Kostyuk, G. S. (1989) Navchalno-vikhovnij proczes i psikhichnij rozvitok osobistosti [Educational process and mental development of personality]. K. : Rad. shkola [in Ukrainian]

8. Panok, V.G. (2016) Psikhologichna sluzhba [Psychological service]. Kiyiv: Ni`ka-Czentr [in Ukrainian]

9. Strakh z SRSR: chomu ukrayinczi boyatsya psikhologiv [Fear of the USSR: why Ukrainians are afraid of psychologists] 24tv.ua Retrieved from https://24tv.ua/health/strah z srsr chomu ukrayintsiv boyatsya_psihologiv_n1093722 [in Ukrainian]

10. Strakh psikhologov i psikhoterapii [Fear of psychologists and psychotherapy] www.b17.ru Retrieved from https://www.b17.ru/article/73131/ a [in Russian].

11. Cossum, Gr. Why are some people afraid of psychologists? Retrieved from https://www.quora.com/Whyare-some-people-afraid-of-psychologists-therapists

12. Hale,M.5CommonFears ThatKeepPeopleOutOfTherapyRetrievedfromhttps://www.mindbodygreen.com/ 0-13317/5-common-fears-that-keep-people-out-of-therapy.html 